vised centrally and locally by democratically elected representatives of the profession.I am, etc.,

Glasgow W.2.

Jack E. Miller.

SIR,-The B.M.A. has had its critics in the past, myself numbered among them, but it takes a confused and worried man indeed to seek evil intent in the wish of the B.M.A. to offer " concessionary rates" (never denied by Dr. Ivor Jones, incidentally) to its members who may wish to make use of a service which will undoubtedly be of the greatest benefit to most of us if the Charter negotiations are brought to a successful conclusion.

Indeed, in Sheffield this scheme has been in most successful operation for some two years, first as a 24-hour telephone answering service, then as a combined telephone answering and deputizing service. We here were determined that the scheme would be of the highest possible ethical standards, for the benefit of patients and doctors alike.

Accordingly the scheme in Sheffield has been supervised from the beginning by a local advisory committee of doctors drawn from the B.M.A. Division and the L.M.C., and the latter has approved and appointed (or rejected) every applicant for a post as deputy. This is the method advocated by the Central Advisory Committee of the B.M.A. Emergency Treatment Service to-day, and in my view is absolutely essential for the successful running of an ethical service.

Will Dr. Maxwell now substantiate the allegations of " the unethical approach made by telephone answering services in many cities," and identify the telephone answering services to which he refers? One assumes he has not rushed into print without proof of his allegations. Also if the "treatment service has been rejected by B.M.A. local executives in Liverpool and Manchester on many grounds" perhaps Dr. Maxwell would be good enough to remind them to tell somebody. So far they seem to have forgotten to do so.

None of the doctors forming our local advisory committee has any financial interest in the service, but, as I am quite sure Dr. Maxwell is only too well aware, capital investment is essential for the establishment and administration of any such organization. Ours came from Telephone Answering Services Ltd.; there is no secret about our "implication" in this; and it is with this company that the B.M.A. is negotiating in order to provide a national service. Would Dr. Maxwell care to tell us how he raised his capital ?

If Dr. Maxwell is sincere in his protestation that he does not fear competition let him accept the free publicity his own service has received through these columns and rest assured that the B.M.A. has no intention of forcing its attentions on anyone. The scheme will only operate in any area at the specific request of the members of that particular Division, and Divisional Secretaries have been notified accordingly.-I am, etc.,

Sheffield 11.

W. P. Lambie.

\section{New System of Remuneration}

SIR,-The executive committee of the Tunbridge Wells Division have discussed the report from your Parliamentary Correspondent (20 November, p. 1254). We are gravely disturbed by the assumption of a spokesman for the Minister of Health that general practitioners have accepted the proposals for the new system of remuneration when, in fact, all that has been agreed is that it should go forward to the Review Body for pricing.

We feel strongly that there should not be any misapprehension here, and the true position should be made absolutely clear by the Association's leaders to the profession, the public, and its elected representatives. -We are, etc.,

\section{D. Henderson, Chairman. \\ D. F. FERGIE-WOODS, Hon. Secretary.}

Tunbridge Wells Division,

British Medical Association.

\section{Doctors' Income Guarantee Account}

SIR,-On behalf of the Medical Practice Freedom Fund, established for the purpose of assisting doctors who resign from the N.H.S., I am grateful to Dr. I. L. Loch and his colleagues in Nottingham (6 November, p. 1128) for their timely support. If their initiative can be followed up on a nationwide scale the fund will be in a position to guarantee an adequate income where needed, to any doctor who resigns from the N.H.S. wherever he may be.

Colleagues who desire to be associated with this aim should send their contributions either to Dr. A. J. Wainwright, 28 Queslett Road, Birmingham 22A, or direct to Barclays Bank, Oldbury, Birmingham, making their cheques payable to either the Medical Practice Freedom Fund or Doctors' Income Guarantee Account.

Contributions so far received to the M.P.F.F. amount to $£ 1,707$ (with promised future monthly sums of £405), and to the D.I.G.A. \&355, the latter entirely from the Nottingham area. The Trustees of the M.P.F.F. are D. C. L. Burges, D. H. Johnson, Gilbert R. Smith, A. J. Wainwright, and $\mathrm{H}$. Barrada.-I am, etc.,

Birmingham 32.

H. BARRADA.

\section{Getting Our Priorities Right}

SIR,-The current trend in medicine is the application of screening methods to "highrisk groups." It seems to us that this development should make us reassess some of the things we do almost automatically because we have always done them. A good example is afforded by the routine investigations to which we subject our antenatal patients. No one will deny the need to know about haemoglobin level and blood group, but what about the Wassermann reaction and Kahn? In five years' experience of busy general-practice obstetrics (with an estimated 500 home confinements between us) we have not picked up one single positive, but in the last 100 patients we have found, as have others, ${ }^{1} 10 \%$ with " significant bacteriuria "and this only because of special facilities we have ourselves made available in our group partnership. ${ }^{1}$

There is a ceiling on what the community is prepared to pay for medical services. If Wassermann reactions in pregnancy give such a relatively low yield of positives, as we believe they do, is it not time this routine procedure, hallowed by tradition, was dropped in favour of something a little less "sterile"? All concerned with the welfare of antenatal patients should be encouraged to uncover and follow-up the symptomless but "significant" bacteriuria.-We are, etc.,
Edinburgh.
J. D. E. KNox.

G. MacNaughtan.

\section{REPERENCE}

MacNaughtan, G., Curr. med. Abstr. Practit., $1965,5,45$.

\section{Laboratory Animals for Rheumatism Research}

SIR,-The Nuffield Foundation, as part of its programme of research into possible underlying causes of rheumatic disease, is anxious to intensify the search for naturally occurring forms of rheumatoid, or rheumatoid-like, lesions in animals suitable for laboratory study. A naturally occurring rheumatoid arthritis in monkeys, for example, would have important implications for the controlled study of the disease. The fact that no evidence-or very little-has so far been obtained that this affliction of man is shared by other primates may simply be due to the almost total preponderance of young animals among those which have been available for study. The Foundation would now like to extend the search to cover a reasonably large sample of older monkeys, and to submit to expert examination the hands and feet (to include wrist- and ankle-joints) of elderly monkeys, preferably of known age.

I would be very grateful to anyone who could put me in touch with possible sources of such material. Centres already concerned in primate studies, in the laboratory or in the field, and where colonies of monkeys are maintained over their natural life span, would evidently be in the best position to help. Would anyone able and willing to help please be kind enough to get in touch with me stating what numbers, species, and age-groups of monkeys could be made available for examination? In some cases it might be possible to arrange for on-the-spot $x$-radiography. In other cases-e.g., following death-it might be possible to send specimens, suitably preserved, to the rheumatologist who would be examining the joints for the Foundation. Suitable instructions about this, and any other help required, which may include defrayment of expenses, can then be given according to circumstances.-I am, etc.,

$$
\begin{aligned}
& \text { The Nuffield Foundation, BRIAN Young. } \\
& \text { Nuffield Lodge, } \\
& \text { Regent's Park, } \\
& \text { London N.W.1. }
\end{aligned}
$$

Corrections.-In the letter by Mr. W. B. S. Crawford entitled "The Second Report" (27 November, p. 1312) the third sentence of the second paragraph should have read: "Do our negotiators not remember the history of the previous attempts to foist ' merit' awards on an unwilling profession and of the contempt with which these were reiected by the Representative Body and the Conference of L.M.C.s?"

In the letter entitled "Royal Medico-Psychological Association" by Dr. William Sargant (27 Novemher, p. 1313) the first sentence of the last paragraph should have read: "The meeting approved the proposed new by-laws, subject to some amendments and improvements." 